DOI: https://doi.org/10.47405/mjssh.v6i9.1008

\begin{tabular}{|c|c|}
\hline & Malaysian Journal of Social Sciences and Humanities (MJSSH) \\
\hline Malaysian Journal of & Volume 6, Issue 9, September 2021 \\
\hline 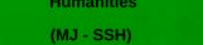 & e-ISSN : 2504-8562 \\
\hline & $\begin{array}{l}\text { Journal home page: } \\
\text { www.msocialsciences.com }\end{array}$ \\
\hline
\end{tabular}

\title{
Analisis Contoh dan Latihan bagi Topik Penambahan dan Penolakan dalam Buku Teks Matematik SJKC
}

\author{
Lim Chien Yee ${ }^{1}$, Roslinda Rosli ${ }^{1}$ \\ ${ }^{1}$ Fakulti Pendidikan, Universiti Kebangsaan Malaysia (UKM) \\ Correspondence: Lim Chien Yee (yuki4090340@gmail.com)
}

\begin{abstract}
Abstrak
Buku teks matematik merupakan medium penting dalam pelaksanaan kurikulum dan merealisasikan matlamat Pendidikan Matematik. Akan tetapi, kajian analisis ciri-ciri contoh dan latihan bagi topik penambahan dan penolakan dalam buku teks matematik SJKC berdasarkan aspek matematik dan kontekstual masih kurang. Analisis ini bertujuan mengenal pasti kelebihan dan kelemahan terhadap contoh dan latihan bagi topik penambahan dan penolakan dalam buku teks matematik dan diharapkan dapat memberikan gambaran kepada penyelidik, penerbit dan penulis buku teks untuk proses penambahbaikan yang akan datang. Dapatan kajian ini menunjukkan bahawa terdapat sejumlah 74 (56\%) contoh dan 57 (44\%) latihan penambahan, manakala bilangan contoh dan latihan penolakan adalah sama, iaitu 59 (50\%) masing-masing. Analisis contoh dan latihan penambahan menunjukkan bahawa contoh satu langkah pengiraan Tahun Satu hingga Tahun Lima adalah lebih banyak daripada latihan satu langkah pengiraan. Tahap Satu mempunyai latihan satu langkah pengiraan yang lebih banyak, manakala Tahun Empat dan Lima mempunyai latihan lebih satu langkah pengiraan yang lebih banyak. Selain itu, Tahun Satu, Empat dan Lima hanya mempunyai contoh bergambar, bercerita atau berjadual. Tahap Satu mempunyai lebih banyak latihan dalam bentuk ayat matematik. Analisis contoh dan latihan penolakan menunjukkan bahawa Tahun Satu mempunyai contoh dan latihan satu langkah pengiraan paling banyak. Tahun Satu mempunyai contoh lebih satu langkah pengiraan yang paling banyak, manakala Tahun Lima mempunyai latihan lebih satu langkah pengiraan yang paling banyak. Contoh yang bergambar, bercerita atau berjadual adalah lebih banyak berbanding dengan latihan bergambar, bercerita atau berjadual bagi Tahun Satu hingga Empat, hanya Tahun Lima mempunyai bilangan contoh dan latihan bergambar, bercerita atau berjadual yang sama.
\end{abstract}

Kata kunci: Buku teks matematik SJKC, contoh dan latihan, penambahan dan penolakan, aspek matematik, aspek kontekstual

\section{Analysis of Examples and Exercises for the Topics of Addition and Subtraction in SJKC Mathematics Textbook}

\begin{abstract}
Mathematics textbooks are deemed as an indispensable medium in the implementation of the national curriculum and the achievement of the desired goals. However, there is a lack of studies pertaining to the topic of addition and subtraction in the Malaysian Chinese National Schools in terms of mathematical and contextual features. This study aims to identify the strengths and weaknesses of the examples and exercises which are found under the topic of additions and subtractions. Through this study, researchers, publishers and textbook writers would have an overall idea about the issues which
\end{abstract}


will be highlighted in this paper with the hope that these insights could be used for future textbook planning. The findings of this study showed that there were total of $74(56 \%)$ examples and $57(44 \%)$ addition exercises, while the number of examples and subtraction exercises were the same, which is 59 (50\%) respectively. Based on the analysis, the examples of single computational procedure are clearly laid out in the Year 1to 5 textbooks. The number of the examples are found relatively more compared to the exercises. Level One textbooks (Year 1 to 3 ) included more exercises of single computational procedure, whereas the Year 4 and 5 textbooks consist of multiple computational procedures exercises. Besides, the use of pictures, stories and tables were found only in Year 1, 4 and 5 textbooks. The level one textbook comprises of more mathematical exercises. The analysis of the examples and subtraction exercises showed that Year 1 textbook had the most single computational procedure examples and exercises. The Year 5 textbook on the other hand, has the most exercises of multiple computational procedures. The Year 1 to 4 textbooks included more pictures, stories and tables in the examples of calculations compared to the exercises. The Year 5 textbook is the only book which inserted the same amount of pictures, stories and tables in both examples of calculations and the exercises.

Keywords: SJKC Mathematics textbook, examples and exercises, addition and subtraction, mathematical aspects, contextual aspects

\section{Pengenalan}

Buku teks matematik merupakan medium penting dalam pelaksanaan kurikulum dan merealisasikan matlamat Pendidikan Matematik. Buku teks matematik juga merupakan petunjuk kepada pelaksanaan kurikulum dan dianggap sebagai pengantar kepada kurikulum dan pelaksanaan kurikulum (Asyrani \& Roslinda, 2020; Gracin, 2018; Reyhani \& Izadi, 2018). Pengajaran matematik guru dipengaruhi oleh buku teks matematik. Hal ini kerana buku teks matematik merupakan sumber asas yang digunakan untuk menyokong pengajaran guru (Stará \& Krčmářová, 2015) dan elemen penting dalam Pendidikan Matematik (Yang et al., 2017). Kajian Lepik et al. (2015) menunjukkan bahawa guru sangat bergantung kepada buku teks ketika merancang pengajaran mereka. Hal ini turut disokong oleh Bingolbali (2020), buku teks memberi kesan terhadap kandungan yang akan diajar oleh guru dan mempengaruhi perkembangan guru. Akan tetapi, kajian Xia (2020) menunjukkan bahawa penggunaan latihan dalam buku teks matematik oleh guru adalah rendah.

Selain itu, buku teks matematik menyediakan murid dengan standard pembelajaran, petunjuk asas dan struktur pengetahuan bagi menjayakan proses pembelajaran matematik. Oleh sebab itu, guru dan murid turut menggunakan buku teks sebagai bahan rujukan utama semasa proses pengajaran dan pembelajaran (Brehmer et al., 2016; Chang \& Silalahi, 2017; Dollah et al., 2019; Ham \& Heinze, 2018; Norberg, 2019). Menurut Bingolbali (2020), buku teks memberi kesan terhadap kandungan yang akan dibelajari oleh murid dan memberi implikasi kepada perkembangan kreativiti, kemahiran pemikiran dan penaakulan murid. Contoh dan latihan dalam buku teks adalah penting bagi murid untuk memperoleh konsep matematik, menguasai teori matematik dan mengembangkan kemahiran matematik (Liu, 2019). Walau bagaimanapun, kajian Xia (2020) menunjukkan bahawa murid-murid menganggap latihan dalam buku teks matematik adalah tidak penting.

Menurut Lusiana dan Andari (2019), antara pelbagai alat atau sumber yang digunakan, buku teks merupakan salah satu alat yang digunakan untuk menyokong dan mengoptimumkan proses pembelajaran matematik. Selain daripada itu, berdasarkan keputusan Programme for International Student Assessment (PISA) 2015, Yang et al. (2017) menyatakan bahawa terdapat hubungan yang kuat antara buku teks matematik yang digunakan dengan pencapaian murid. Maka, kesesuaian contoh dan latihan dalam buku teks matematik sering kali memberi gambaran umum terhadap keseluruhan buku teks matematik (Yang, 2019). Oleh sebab itu, sejak beberapa dekad yang lalu, perhatian terhadap buku teks daripada penyelidikan antarabangsa semakin meningkat. Hal ini turut menyebabkan buku teks menjadi fokus penyelidikan Trends in International Mathematics and Science Study (TIMSS) pada akhir abad ke-20, di mana pada masa itu sebanyak ribuan buah buku teks matematik dari 50 buah negara telah dikaji. Tambahan pula, menurut Ho (2018), salah satu tema perbincangan dalam 
International Congress on Mathematical Education (ICME-10) pada tahun 2004 ialah buku teks matematik.

\section{Sorotan Literatur}

Kecenderungan penurunan pencapaian murid Malaysia dalam TIMSS dari tahun 2003 hingga tahun 2011 merupakan isyarat yang menimbulkan kebimbangan daripada ahli akademik, ahli politik, pihak berkepentingan dan masyarakat umum mengenai kualiti pendidikan di Malaysia. Menurut Mullis et al. (2016), pencapaian murid yang lemah ini adalah disebabkan kekurangan pendedahan terhadap Kemahiran Berfikir Aras Tinggi (KBAT). Sebagai usaha untuk mengatasi masalah ini dan melengkapi Pelan Pembangunan Pendidikan Malaysia (PPPM) 2013-2025 yang mengupayakan pelaksanaan transformasi sistem pendidikan kebangsaan secara menyeluruh, Malaysia telah mengalami beberapa perubahan dalam dasar pendidikan, iaitu dari KBSR (1983-2010) ke KSSR (2011) dan KSSR ke KSSR (semakan 2017).

Pembaharuan kurikulum pendidikan ini turut mendapat perhatian daripada penyelidik-penyelidik tempatan untuk mengkaji dan menganalisis kandungan kurikulum dan buku teks matematik yang baharu ini. Tan et al. (2017) menjalankan kajian analisis perbandingan domain kognitif bagi dua siri (KBSR dan KSSR) buku teks matematik Tahun Empat di Malaysia. Kajian Tan et al. (2017) menunjukkan bahawa sebahagian besar latihan dalam kedua-dua siri buku teks matematik berada dalam domain mengetahui. Akan tetapi, peningkatan telah dilakukan dalam buku teks matematik Tahun Empat versi baharu (KSSR), di mana lebih banyak latihan dalam domain mengaplikasikan dan penaakulan berbanding dengan buku teks matematik KBSR. Kajian Azriana dan Roslinda (2021) pula menunjukkan bahawa buku teks matematik Tahun Empat KSSR (Semakan 2017) mempunyai aras kognitif soalan yang lebih tinggi berbanding dengan buku teks KSSR. Selain daripada itu, kajian Cheng dan Roslinda (2020) pula menganalisis domain kognitif bagi latihan-latihan dalam buku teks matematik Tahun Enam SK dan SJKC. Hasil kajian mereka selari dengan Tan et al. 2018, di mana kebanyakan latihan dalam dua buah buku teks matematik yang dikaji berada dalam domain mengetahui. Namun, hasil kajian ini menunjukkan bahawa tiada perbezaan yang besar bagi latihan berdasarkan domain kognitif dalam kedua-dua buah buku teks.

Berdasarkan ketiga-tiga kajian, didapati bahawa analisis soalan buku teks matematik di Malaysia lebih menumpu kepada domain kognitif soalan. Hal ini kerana didapati pencapaian murid yang kurang memuaskan dalam TIMSS adalah disebabkan murid-murid kurang didedahkan kepada soalan matematik KBAT (Mullis et al., 2016). Menurut kajian Tan et al. (2017) dan Azriana dan Roslinda (2021) pula, didapati bahawa ketiga-tiga siri (KBSR, KSSR dan KSSR Semakan 2017) buku teks matematik Malaysia telah menunjukkan penambahbaikan, di mana lebih banyak soalan matematik berada dalam aras kognitif soalan yang lebih tinggi berbanding dengan buku teks siri lama, di mana ini selaras dengan hasrat pendidikan melahirkan insan yang berfikiran aras tinggi.

Kajian Lessani et al. (2014) mengkaji kandungan buku teks matematik Tingkatan Dua di Malaysia berdasarkan domain kandungan TIMSS. Kajian Lessani et al. (2014) mendapati bahawa buku teks matematik Tingkatan Dua di Malaysia mempunyai sedikit kekurangan, di mana jumlah contoh yang diberikan dalam beberapa topik adalah jauh lebih kurang daripada latihan yang diberikan. Pengagihan bilangan contoh dan latihan dalam buku teks matematik adalah sangat penting kerana pengajaran dan pembelajaran matematik tidak dapat dipisahkan daripada pengajaran contoh. Pandangan ini disokong oleh Ho (2018) yang menyatakan bahawa contoh dalam buku teks matematik mempunyai fungsi yang unik seperti melatih kemahiran berfikir matematik murid yang tidak dapat digantikan. Selain itu, kajian Lessani et al. (2014) juga mendapati bahawa aspek visual dalam buku teks matematik yang dikaji adalah agak lemah dan membosankan murid, di mana terdapat sebilangan yang besar kandungan dipersembahkan dalam warna hitam dan putih sahaja. Tambahan pula, grafik, carta, jadual dan gambar dalam buku teks juga tidak begitu menarik perhatian murid. Selain daripada itu, susun atur dalam buku teks yang dikaji juga tidak begitu baik, ini turut menyebabkan kelihatan kandungan dalam buku teks tersebut kurang menarik. Menurut Ho (2018), penggunaan tema kontekstual dan gambar-gambar yang 
bergabung dengan pengetahuan khusus menyebabkan susun atur buku teks menjadi lebih kaya dan menarik agar dapat merangsang minat murid untuk belajar dengan berkesan.

Secara kesimpulannya, berdasarkan kajian-kajian lepas ini, didapati bahawa kajian analisis ciri-ciri contoh dan latihan bagi penambahan dan penolakan dalam buku teks matematik berdasarkan aspek matematik dan kontekstual adalah masih kurang dan diperlukan.

\section{Bilangan Jenis Soalan}

Bilangan contoh dan latihan dalam buku teks matematik merupakan salah satu faktor menjayakan proses pengajaran dan pembelajaran matematik. Murid-murid lebih gemar menggunakan buku teks semasa menyiapkan kerja sekolah kerana mereka dapat mengulang kaji kemahiran yang telah mereka mempelajari (Alabdulaziz, 2021). Murid boleh memerhatikan cara penyelesaian yang disediakan dalam contoh dan mengaplikasikan cara penyelesaian tersebut ke dalam latihan lain (Norqvist, 2018). Menurut Pei et al. (2016), dalam pembelajaran matematik, terutamanya topik nombor dan operasi, murid memerlukan latihan yang berulang kali untuk menguasai dan mengukuhkan pemahaman terhadap logaritma dan mahir dalam pengiraan agar dapat mengaplikasikannya ke dalam penyelesaian masalah yang sebenar dengan lebih baik.

Akan tetapi, punca murid melakukan kesilapan pengiraan adalah disebabkan kekurangan contoh dalam buku teks matematik (Makonye \& Fakude, 2016). Wang (2017) menjalankan kajian terhadap dua versi buku teks matematik yang paling popular digunakan di negara China menunjukkan bahawa jurang perbezaan bilangan soalan dalam kedua-dua versi buku teks adalah agak besar. Lessani et al. (2014) pula menjalankan kajian terhadap buku teks matematik Tingkatan Dua pula menunjukkan bahawa jumlah contoh yang dinyatakan dalam buku teks adalah kurang berbanding dengan bilangan latihan dalam buku teks. Bilangan contoh dalam buku teks matematik yang mencukupi adalah sangat penting kerana murid-murid boleh mengulang kaji demi menguasai dan mengukuhkan kemahiran yang dipelajari serta menerapkannya ke dalam penyelesaian masalah praktikal dengan lebih baik. Sebaliknya, bilangan latihan yang terlalu banyak pula akan membebankan murid. Maka, kata kunci untuk mengoptimumkan fungsi latihan dalam buku teks matematik bukan terletak pada "kuantiti" latihan, tetapi pada "kualiti" latihan (Pei et al., 2016). Oleh sebab itu, bilangan latihan dalam buku teks matematik perlu ditimbang dengan wajar supaya kecekapan dan kualiti pembelajaran murid dijamin (Pei et al., 2016).

\section{Aspek Matematik}

Aspek matematik merujuk kepada bilangan langkah pengiraan bagi soalan matematik (Li, 2000). Murid berpencapaian matematik pada tahap yang tinggi mungkin akan berasa bosan dan kurang mencabar sekiranya terlalu banyak contoh dan latihan dalam dalam buku teks matematik sekolah rendah hanya melibatkan satu langkah pengiraan (single computational procedure). Hal ini turut menyebabkan mereka tidak berminat menggunakan buku teks sebagai sumber pembelajaran. Buku teks merupakan sumber utama yang membantu murid mengembangkan kemahiran pemikiran kritis mereka. Hal ini kerana murid berpencapaian matematik tinggi sudi menggunakan lebih banyak masa untuk menganalisis contoh dan latihan (Norqvist, 2018). Selain itu, mereka juga lebih cenderung melakukan penyemakan semula dan mencari cara penyelesaian dengan sendiri. Oleh itu, penyediaan contoh dan latihan yang pelbagai jenis dan seimbang dalam buku teks matematik adalah sangat penting kerana ia akan mempengaruhi cara pemikiran seseorang murid dan mempengaruhi kualiti proses pengajaran dan pembelajaran (Gracin, 2018).

Kajian Yeh (2019) mendapati bahawa murid yang berpencapaian matematik pada tahap yang kurang baik, terpaksa menerima pengetahuan secara pasif kerana mereka tidak diberikan masa yang mencukupi untuk memahami contoh dan menyelesaikan latihan yang diberikan. Hal ini merupakan kesan daripada bilangan contoh dan latihan dalam buku teks matematik yang melibatkan lebih daripada satu langkah pengiraan yang terlalu banyak. Abdullah et al. (2016) berpendapat bahawa murid-murid akan menghadapi kesukaran dalam proses penggabungan konsep dan prosedur untuk membentuk cara 
penyelesaian yang baharu apabila mereka diberikan masalah matematik yang mengandungi pelbagai konsep dan langkah penyelesaian yang banyak.

Reka bentuk setiap contoh dan latihan memberi kesan yang besar terhadap proses pengajaran guru dan pembelajaran matematik murid (Yang, 2019), ini kerana latihan-latihan dalam buku teks matematik membolehkan murid-murid mempraktikkan kemahiran yang dipelajari (Gracin, 2018). Tambahan pula, menurut Ng dan Dindyal (2016), guru-guru lebih gemar memilih latihan yang dapat mencabar murid. Maka, penyediaan kepelbagaian jenis contoh dan latihan dalam buku teks matematik adalah sangat penting kerana dapat menggalakkan murid-murid lebih berfikir kritis dan mencabar serta memberikan peluang kepada mereka mengembangkan pemahaman dan kemahiran yang dipelajari ke tahap yang lebih tinggi (Gracin, 2018). Kajian Hadar (2017) mendapati bahawa sekiranya buku teks menyediakan latihan yang membolehkan murid menuntut tahap pemahaman yang lebih tinggi, maka murid yang menggunakan buku ini akan mendapat pencapaian yang lebih tinggi.

\section{Aspek Kontekstual}

Aspek kontekstual merujuk kepada cara soalan matematik digambarkan dalam buku teks (Hwang et al., 2021). Kepelbagaian aspek kontekstual dapat membantu murid memikir pelbagai strategi penyelesaian masalah (Tan et al., 2018). Proses pembelajaran murid bergantung pada tahap minat dan tahap kesukaran topik yang dipelajari, manakala ilustrasi atau gambar dapat membantu murid memahami topik yang diajar dan meningkatkan penyertaan murid dalam proses pembelajaran (Yang, 2019). Menurut sembilan peristiwa pengajaran oleh Gagne, dalam peristiwa keempat, iaitu guru akan mengemukakan kandungan atau topik baharu kepada murid, murid-murid lebih cenderung mengingati gambar atau grafik berbanding dengan hanya menggunakan perkataan (Noriati et al., 2017). Selain itu, salah satu faktor yang mempengaruhi perkembangan murid terhadap konsep matematik pada peringkat awal ialah penggunaan contoh dan latihan yang pelbagai jenis persembahan (Yang, 2019). Cara persembahan contoh dan latihan dalam buku teks matematik adalah sangat penting kerana guru-guru menggunakan buku teks sebagai sumber asas perancangan pengajaran mereka (Stará \& Krčmářová, 2015).

Namun, ini bercanggah dengan Norberg (2019) yang kajiannya menunjukkan bahawa gambar dalam beberapa contoh dan latihan dalam buku teks matematik mengelirukan murid-murid dan memerlukan penjelasan daripada guru. Oleh sebab itu, penggunaan visual dan gabungan gambar dengan perkataan dalam buku teks harus dirancang dan digunakan dengan cara yang lebih kondusif supaya dapat menyokong pembelajaran (Behnke, 2018). Dalam kajian Li (2000) mencadangkan dua kriteria aspek kontekstual, iaitu contoh dan latihan dalam bentuk ayat matematik dan contoh dan latihan yang bergambar, bercerita atau berjadual.

\section{Metod Kajian}

Reka bentuk penyelidikan ini merupakan kajian tinjauan. Dalam kajian, pengkaji akan meninjau contoh dan latihan bagi topik penambahan dan penolakan dalam buku teks matematik Sekolah Jenis Kebangsaan Cina (SJKC( KSSR (Semakan 2017) secara deskriptif. Data kajian ini akan dikumpulkan secara kualitatif, manakala data-data yang dikumpulkan pula akan dianalisis secara kuantitatif. Contoh dan latihan bagi topik penambahan dan penolakan dalam buku teks matematik SJKC merupakan item yang dikaji. Item-item ini dianalisis berdasarkan aspek matematik dan aspek kontekstual.

Dalam kajian ini, analisis kajian dibahagikan kepada dua fasa, iaitu fasa pertama analisis terhadap bilangan jenis soalan, aspek matematik dan aspek kontekstual, manakala fasa kedua pula ialah analisis terhadap contoh dan latihan dalam buku teks matematik berdasarkan aspek matematik dan aspek kontekstual. Tambahan pula, semua contoh dan latihan akan diterjemahkan kepada Bahasa Malaysia supaya mudah difahami oleh semua pembaca. 


\section{Bahan}

Kajian ini menggunakan kaedah pensampelan bertujuan, di mana buku teks matematik yang dipilih ialah buku teks matematik SJKC KSSR (Semakan 2017) dari Tahun Satu hingga Tahun Lima. Lima buah buku teks matematik dipilih sebagai sampel kajian, iaitu buku teks matematik SJKC Tahun Satu hingga Tahun Tiga Jilid 1, Tahun Empat dan Tahun Lima. Buku teks versi ini dipilih kerana versi ini merupakan versi terbaharu yang diterbitkan selepas pembaharuan kurikulum sejak tahun 2011. Buku teks matematik Tahun Enam KSSR tidak dipilih sebagai sasaran kajian analisis ini kerana edisi baharu buku teks matematik Tahun Enam KSSR (Semakan 2017) akan diterbitkan pada tahun 2022, buku teks versi ini tidak akan digunakan lagi. Maka, analisis terhadap buku teks versi ini adalah kurang bermakna. Item-item yang dikaji dikumpulkan berpandukan Dokumen Standard Kurikulum dan Pentaksiran (DSKP), di mana sebarang soalan matematik yang berkaitan dengan topik penambahan dan penolakan akan dijadikan item analisis.

\section{Kriteria Analitik}

Semua soalan dalam buku teks matematik SJKC KSSR (Semakan 2017) dari Tahun Satu hingga Tahun Lima bagi topik penambahan dan penolakan akan dianalisis berdasarkan ketiga-tiga aspek yang dibincangkan di bawah ini.

\section{Jenis Soalan}

Semua soalan dalam buku teks matematik dikategorikan kepada dua jenis, iaitu contoh dan latihan. Dalam kajian ini, contoh merujuk kepada jenis soalan yang dibekalkan cara penyelesaian dan soalan yang digunakan sebagai contoh soalan dalam aktiviti pengajaran. Tambahan pula, contoh dalam buku teks matematik diberikan nombor soalan dan berada pada bahagian depan setiap topik. Tambahan pula, sekiranya soalan tersebut dibekalkan kaedah penyelesaian, manakala jawapan tidak dibekalkan juga dianggapkan sebagai contoh soalan. Latihan pula merujuk kepada jenis soalan yang digunakan sebagai soalan ulang kaji bagi murid dan tidak dibekalkan cara penyelesaian dan jawapan. Dalam buku teks matematik, soalan di bawah tajuk seperti“练一练”(cuba jawab), “自我学习” (uji minda) dan “完成 以下习题” (cuba ini) merupakan latihan bagi topik tersebut.

Selain itu, sekiranya contoh atau latihan dibahagikan kepada beberapa bahagian, maka dalam kajian ini setiap bahagian akan diambil kira sebagai satu contoh atau latihan. Hal ini bermaksud sekiranya contoh tersebut terdapat tiga bahagian (a), (b) dan (c), maka akan diambil kira sebagai tiga contoh. Setiap soalan matematik dalam buku teks matematik dikodkan mengikut jenis soalan, di mana contoh akan dikodkan sebagai (C) dan latihan pula dikodkan sebagai (L).

\section{Aspek Matematik}

Dalam kajian ini, aspek matematik merujuk kepada bilangan langkah pengiraan bagi contoh dan latihan untuk mendapat jawapan. Aspek matematik kajian ini dibahagikan kepada dua kategori, iaitu satu langkah pengiraan dan lebih daripada satu langkah pengiraan. Dalam kajian ini, contoh dan latihan akan dikodkan mengikut bilangan langkah pengiraannya, iaitu satu langkah pengiraan dikodkan sebagai P1 dan lebih daripada satu langkah pengiraan dikodkan sebagai P2.

\section{Aspek Kontekstual}

Dalam kajian ini, aspek kontekstual merujuk kepada cara persembahan contoh dan latihan dalam buku teks matematik. Aspek kontekstual kajian ini dibahagikan kepada dua jenis, iaitu contoh dan latihan dalam bentuk ayat matematik dan bergambar, bercerita atau berjadual. Contoh dan latihan dalam bentuk ayat matematik dikodkan sebagai AM, manakala contoh dan latihan yang bergambar, bercerita atau berjadual pula dikodkan sebagai GCJ. Jadual 3 menunjukkan bahawa cara pengekodan soalan matematik berdasarkan jenis soalan, aspek matematik dan aspek kontekstual. 
DOI: https://doi.org/10.47405/mjssh.v6i9.1008

Jadual 1: Pengekodan soalan matematik berdasarkan aspek kontekstual

\begin{tabular}{|c|c|c|c|}
\hline \multicolumn{4}{|c|}{ Buku teks matematik Tahun Lima SJKC (muka surat 16 dan 17) } \\
\hline \multirow[t]{2}{*}{ Soalan } & Jenis Soalan & $\begin{array}{c}\text { Aspek } \\
\text { Matematik }\end{array}$ & $\begin{array}{c}\text { Aspek } \\
\text { Kontekstual } \\
\end{array}$ \\
\hline & & Kod & \\
\hline
\end{tabular}

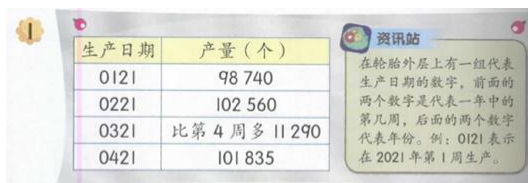

a 第 1 周和第 2 周共生产了多少个轮胎?

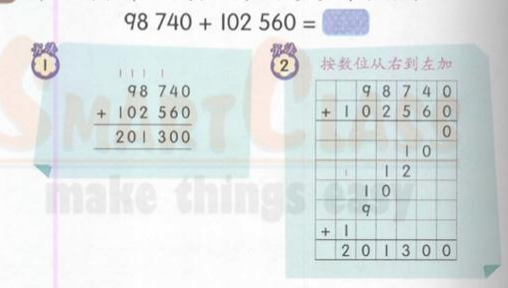

$\begin{array}{lll}\text { C } & \text { P1 } & \text { GCJ }\end{array}$

\begin{tabular}{|c|c|}
\hline Tarikh Pengeluaran & Kuantiti (biji) \\
\hline 0121 & 98740 \\
\hline 0221 & 102560 \\
\hline 0321 & $\begin{array}{c}11290 \text { lebih daripada } \\
\text { minggu keempat }\end{array}$ \\
\hline 0421 & 101835 \\
\hline
\end{tabular}

Berapakah biji tayar yang dikeluarkan dalam minggu pertama dan minggu kedua?

$98740+102560=201300$

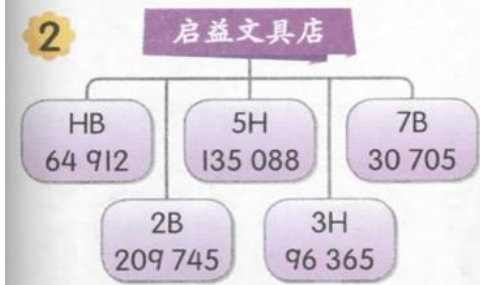

$\mathrm{C}$

P2

GCJ

启益文具店共卖了多少支 $\mathrm{HB} 、 2 \mathrm{~B}$ 和 $5 \mathrm{H}$ 笔?

$$
64912+209745+135088=
$$

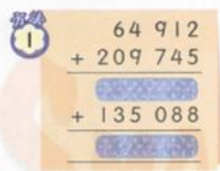

(2) $64912+209745+135088$

$=64912+135088+209745$

$=200000+209745$

$=6$

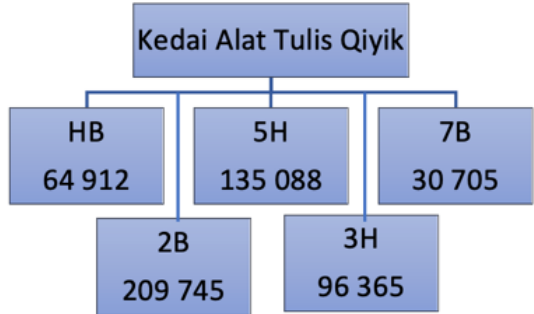

Berapakah jumlah jualan pensel $\mathrm{HB}, 2 \mathrm{~B}$ dan 5H bagi kedai alat tulis Qiyik?

$64912+209745+135088$

$=$ 


\section{Kesahan dan Kebolehpercayaan}

Dua orang penyelidik dijemput sebagai pengekod kajian ini. Sejumlah 25 contoh dan latihan bagi topik penambahan dan 25 contoh dan latihan bagi topik penolakan dalam buku teks matematik Tahun Satu hingga Tahun Lima dipilih secara rawak, kemudian akan dikodkan secara bebas oleh dua orang penyelidik cara pengekodan kajian ini. Perbezaan antara kedua-dua orang penyelidik dalam pengekodan contoh dan latihan akan dibincangkan dan diselaraskan sehingga mencapai sekurangkurangnya 90\% (Cheng \& Roslinda, 2020; Ho, 2018) persetujuan bagi keseluruhan contoh dan latihan yang dikodkan.

\section{Hasil Kajian}

\section{Analisis Jumlah Soalan bagi Topik Penambahan dan Penolakan}

Menurut analisis, didapati bahawa jumlah soalan penambahan bagi Tahun Satu hingga Tahun Lima sebanyak 131 (53\%), manakala jumlah soalan penolakan bagi Tahun Satu hingga Tahun Lima pula sebanyak 118 (47\%). Selain itu, didapati bahawa jumlah soalan penolakan adalah kurang 13 daripada soalan penambahan.

\section{Analisis Bilangan Soalan bagi Topik Penambahan dan Penolakan}

Berdasarkan Rajah 1, didapati bahawa Tahun Satu mempunyai jumlah bilangan soalan dalam topik penambahan dan penolakan yang paling tinggi, iaitu sebanyak 66 soalan dan 65 soalan. Selain itu, jumlah bilangan soalan dalam topik penambahan Tahun Empat dan Lima pula paling rendah, iaitu hanya hanya 10 soalan. Akan tetapi, soalan penolakan dalam buku teks matematik Tahun Empat pula paling kurang, iaitu hanya 7 soalan sahaja.

Rajah 1: Bilangan soalan dalam topik penambahan dan penolakan

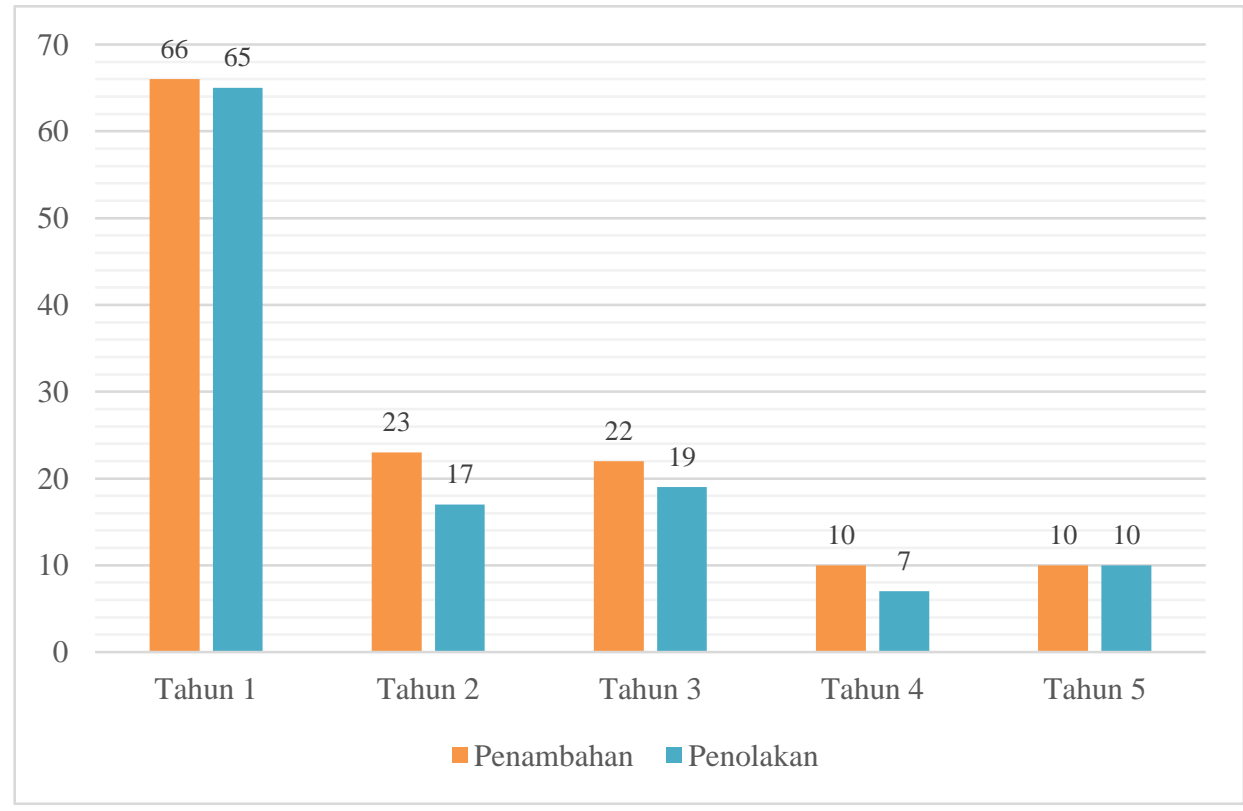


DOI: https://doi.org/10.47405/mjssh.v6i9.1008

\section{Analisis Bilangan Jenis Soalan, Aspek Matematik dan Aspek Kontekstual}

Fasa pertama kajian ini ialah analisis terhadap bilangan jenis soalan, aspek matematik dan aspek kontekstual bagi soalan topik penambahan dan penolakan dalam buku teks matematik SJKC KSSR (Semakan 2017).

\section{Analisis Bilangan Contoh dan Latihan}

Menurut Jadual 4, didapati bahawa buku teks Tahun Satu hingga Lima mempunyai sejumlah 74 contoh (56\%) topik penambahan dan 57 (44\%) latihan topik penambahan. Selain itu, didapati bahawa bilangan contoh dan latihan topik penambahan bagi Tahun Satu adalah paling tinggi, iaitu 38 (58\%) dan 28 (42\%). Jumlah bilangan contoh dan latihan topik penambahan bagi Tahun Empat dan Lima adalah sama, iaitu 10 soalan. Tambahan pula, berdasarkan Jadual 4, didapati juga bahawa jumlah bilangan contoh dan latihan bagi topik penambahan menunjukkan tren semakin kurang. Berdasarkan Jadual 4, didapati bahawa buku teks Tahun Satu hingga Lima mempunyai bilangan contoh dan latihan topik penolakan yang sama, iaitu $59(50 \%)$ masing-masing. Selain itu, didapati juga bahawa bilangan contoh dan latihan topik penolakan bagi Tahun Satu adalah paling tinggi, iaitu $30(46 \%)$ dan $35(54 \%)$. Jumlah bilangan contoh dan latihan topik penolakan bagi Tahun Empat pula paling kurang, iaitu 4 (57\%) soalan contoh dan $3(43 \%)$ soalan latihan.

Jadual 2: Bilangan contoh dan latihan dalam topik penambahan

\begin{tabular}{|c|c|c|c|c|}
\hline \multirow{3}{*}{ Buku Teks } & \multicolumn{2}{|c|}{ Penambahan } & \multicolumn{2}{|c|}{ Penolakan } \\
\hline & Contoh & Latihan & Contoh & Latihan \\
\hline & Kekerapan (\%) & Kekerapan (\%) & Kekerapan (\%) & Kekerapan (\%) \\
\hline Tahun Satu & $38(58)$ & $28(42)$ & $30(46)$ & $35(54)$ \\
\hline Tahun Dua & $13(57)$ & $10(43)$ & $9(53)$ & $8(47)$ \\
\hline Tahun Tiga & $14(64)$ & $8(36)$ & $12(63)$ & $7(37)$ \\
\hline Tahun Empat & $4(40)$ & $6(60)$ & $4(57)$ & $3(43)$ \\
\hline Tahun Lima & $5(50)$ & $5(50)$ & $4(40)$ & $6(60)$ \\
\hline Jumlah & $74(56)$ & $57(44)$ & $59(50)$ & $59(50)$ \\
\hline
\end{tabular}

\section{Analisis Aspek Matematik Soalan Matematik}

Jadual 5 menunjukkan bahawa $103(79 \%)$ soalan topik penambahan merupakan soalan yang hanya mempunyai satu langkah pengiraan, manakala hanya $28(21 \%)$ soalan topik penambahan merupakan soalan yang mempunyai lebih satu langkah pengiraan. Berdasarkan Jadual 5, didapati bahawa 66 soalan $(100 \%)$ topik penambahan Tahun Satu merupakan soalan yang hanya mempunyai satu langkah pengiraan. Selain itu, didapati juga bahawa soalan topik penambahan bagi Tahap Satu (Tahun Satu, Dua dan Tiga) yang mempunyai satu langkah pengiraan adalah melebihi 50\% (100\%, 70\% dan 68\%). Tambahan pula, peratusan soalan topik penambahan yang mempunyai lebih satu langkah pengiraan menunjukkan tren peningkatan, iaitu daripada 30\% (Tahun Dua), 32\% (Tahu Tiga), 70\% (Tahun Empat dan Lima).

Jadual 5: Analisis bilangan soalan topik penambahan berdasarkan aspek matematik

\begin{tabular}{lcc}
\hline Buku Teks & Satu langkah pengiraan (P1) & Lebih satu langkah pengiraan (P2) \\
\cline { 2 - 3 } & Kekerapan $(\%)$ & Kekerapan $(\%)$ \\
\hline Tahun Satu & $66(100)$ & $0(0)$ \\
Tahun Dua & $16(70)$ & $7(30)$ \\
Tahun Tiga & $15(68)$ & $7(32)$ \\
Tahun Empat & $3(30)$ & $7(70)$ \\
Tahun Lima & $3(30)$ & $7(70)$ \\
Jumlah & $103(79)$ & $28(21)$ \\
\hline
\end{tabular}


Menurut Jadual 6, didapati bahawa $92(78 \%)$ soalan topik penolakan merupakan soalan yang hanya mempunyai satu langkah pengiraan, manakala hanya $26(22 \%)$ soalan topik penolakan merupakan soalan yang mempunyai lebih satu langkah pengiraan. Selain daripada itu, didapati bahawa $17(100 \%)$ soalan topik penolakan bagi Tahun Dua ialah soalan hanya mempunyai satu langkah pengiraan. Selain itu, didapati bahawa peratusan soalan topik penolakan hanya satu langkah pengiraan (78\%) adalah lebih tinggi berbanding dengan soalan yang melebihi satu langkah pengiraan (22\%).

Jadual 6: Analisis bilangan soalan topik penolakan berdasarkan aspek Matematik

\begin{tabular}{lcc}
\hline Buku Teks & Satu langkah pengiraan (P1) & Lebih satu langkah pengiraan (P2) \\
\cline { 2 - 3 } & Kekerapan $(\%)$ & Kekerapan $(\%)$ \\
\hline Tahun Satu & $56(86)$ & $9(14)$ \\
Tahun Dua & $17(100)$ & $0(0)$ \\
Tahun Tiga & $12(63)$ & $7(37)$ \\
Tahun Empat & $3(43)$ & $4(57)$ \\
Tahun Lima & $4(40)$ & $6(60)$ \\
Jumlah & $92(78)$ & $26(22)$ \\
\hline
\end{tabular}

\section{Analisis Aspek Kontekstual Soalan Matematik}

Jadual 7 menunjukkan bahawa 71 (54\%) soalan topik penambahan dalam bentuk ayat matematik, 60 (46\%) pula merupakan soalan topik penambahan bergambar, bercerita atau berjadual. Selain itu, didapati bahawa hanya Tahun Satu dan Dua mempunyai soalan dalam bentuk ayat matematik yang lebih banyak daripada soalan bergambar, bercerita atau berjadual. Selain daripada itu, peratusan jenis soalan yang bergambar, bercerita atau berjadual semakin meningkat, di mana Tahun Satu 30\%, Tahun Dua 43\%, Tahun Tiga 55\%, Tahun Empat 80\% dan Tahun Lima 100\%. Sebaliknya, soalan dalam bentuk ayat matematik pula semakin kurang, di mana Tahun Satu 70\%, Tahun Dua 57\%, Tahun Tiga 45\%, Tahun Empat 20\% dan tiada soalan bentuk ayat matematik bagi Tahun Lima.

Jadual 7: Analisis bilangan soalan topik penambahan berdasarkan aspek kontekstual

\begin{tabular}{lcc}
\hline \multirow{2}{*}{ Buku Teks } & Ayat Matematik (AM) & Bergambar/ bercerita/ berjadual (GCJ) \\
\cline { 2 - 3 } & Kekerapan $(\%)$ & Kekerapan $(\%)$ \\
\hline Tahun Satu & $46(70)$ & $20(30)$ \\
Tahun Dua & $13(57)$ & $10(43)$ \\
Tahun Tiga & $10(45)$ & $12(55)$ \\
Tahun Empat & $2(20)$ & $8(80)$ \\
Tahun Lima & $0(0)$ & $10(100)$ \\
Jumlah & $71(54 \%)$ & $60(46 \%)$ \\
\hline
\end{tabular}

Jadual 8 menunjukkan bahawa $47(40 \%)$ soalan topik penolakan dalam bentuk ayat matematik, 71 (60\%) soalan topik penolakan bergambar, bercerita atau berjadual. Berdasarkan Jadual 8, didapati bahawa hanya buku teks Tahun Tiga mempunyai soalan bentuk matematik melebihi soalan bergambar, bercerita atau berjadual. Selain itu, didapati juga bahawa bilangan soalan bergambar, bercerita atau berjadual semakin meningkat, di mana Tahun Satu 62\%, Tahun Dua 59\%, Tahun Tiga 47\%, Tahun Empat 57\% dan Tahun Lima 80\%.

Jadual 8: Analisis bilangan soalan topik penolakan berdasarkan aspek kontekstual

\begin{tabular}{lcc}
\hline \multirow{2}{*}{ Buku Teks } & Ayat Matematik (AM) & Bergambar/ bercerita/ berjadual (GCJ) \\
\cline { 2 - 3 } & Kekerapan (\%) & Kekerapan (\%) \\
\hline Tahun Satu & $25(38)$ & $40(62)$ \\
Tahun Dua & $7(41)$ & $10(59)$
\end{tabular}


DOI: https://doi.org/10.47405/mjssh.v6i9.1008

\begin{tabular}{lcc} 
Tahun Tiga & $10(53)$ & $9(47)$ \\
Tahun Empat & $3(43)$ & $4(57)$ \\
Tahun Lima & $2(20)$ & $8(80)$ \\
Jumlah & $47(40)$ & $71(60)$ \\
\hline
\end{tabular}

\section{Analisis Aspek Matematik dan Aspek Kontekstual Contoh dan Latihan}

Fasa kedua kajian ini ialah analisis terhadap ciri-ciri contoh dan latihan bagi topik penambahan dan penolakan dalam buku teks matematik berdasarkan aspek matematik dan aspek kontekstual.

\section{Analisis Ciri-ciri Contoh dan Latihan Berdasarkan Aspek Matematik}

a) Analisis contoh dan latihan topik penambahan berdasarkan aspek matematik

Berdasarkan Rajah 2, didapati bahawa contoh satu langkah pengiraan bagi topik penambahan dalam kelima-lima buah buku teks yang dikaji adalah lebih banyak daripada latihan satu langkah pengiraan. Selain itu, Rajah 2 juga menunjukkan bahawa contoh lebih satu langkah pengiraan bagi Tahap Satu adalah lebih banyak berbanding dengan latihan lebih satu langkah pengiraan. Akan tetapi, Tahun Empat dan Lima pula, latihan lebih satu langkah pengiraan adalah lebih tinggi berbanding dengan contoh lebih satu langkah pengiraan.

Rajah 2: Analisis contoh dan latihan topik penambahan berdasarkan aspek matematik

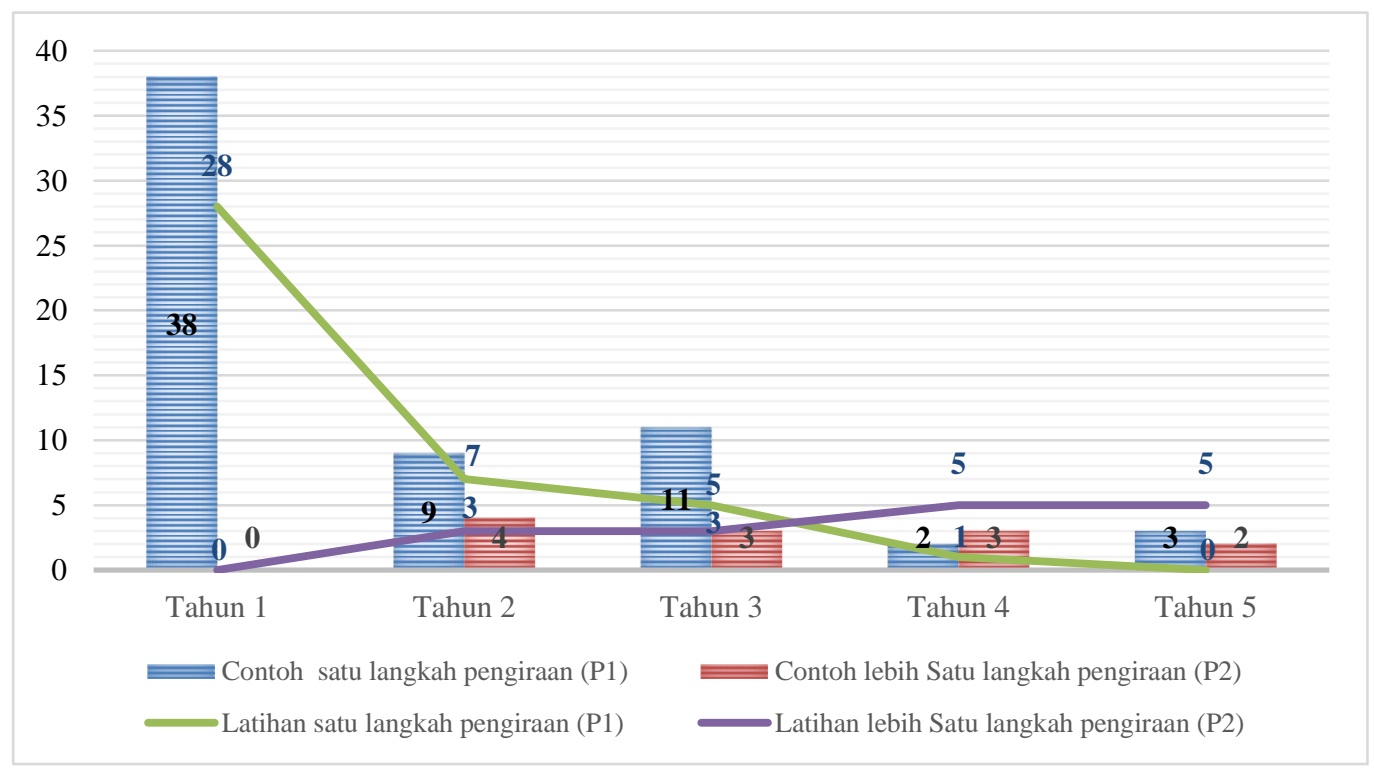

b) Analisis ciri-ciri contoh dan latihan topik penolakan berdasarkan aspek matematik

Rajah 3 menunjukkan bahawa latihan satu langkah pengiraan bagi Tahun Satu dan Tahun Empat adalah lebih banyak berbanding dengan contoh satu langkah pengiraan. Sebaliknya, contoh satu langkah pengiraan bagi Tahun Dua dan Tiga adalah lebih banyak berbanding dengan latihan satu langkah pengiraan. Bagi Tahun Lima pula, bilangan contoh satu langkah pengiraan dan latihan satu langkah pengiraan adalah sama. Selain itu, Rajah 3 menunjukkan bahawa buku teks matematik Tahun Dua tidak menyediakan contoh dan latihan lebih satu langkah pengiraan bagi topik penolakan. Contoh lebih satu langkah pengiraan bagi Tahun Satu, Tahun Tiga dan Tahun Empat adalah lebih banyak daripada latihan lebih satu langkah pengiraan, hanya Tahun Lima mempunyai latihan lebih satu langkah pengiraan yang lebih tinggi. 
DOI: https://doi.org/10.47405/mjssh.v6i9.1008

Rajah 3: Analisis ciri-ciri contoh dan latihan topik penolakan berdasarkan aspek matematik

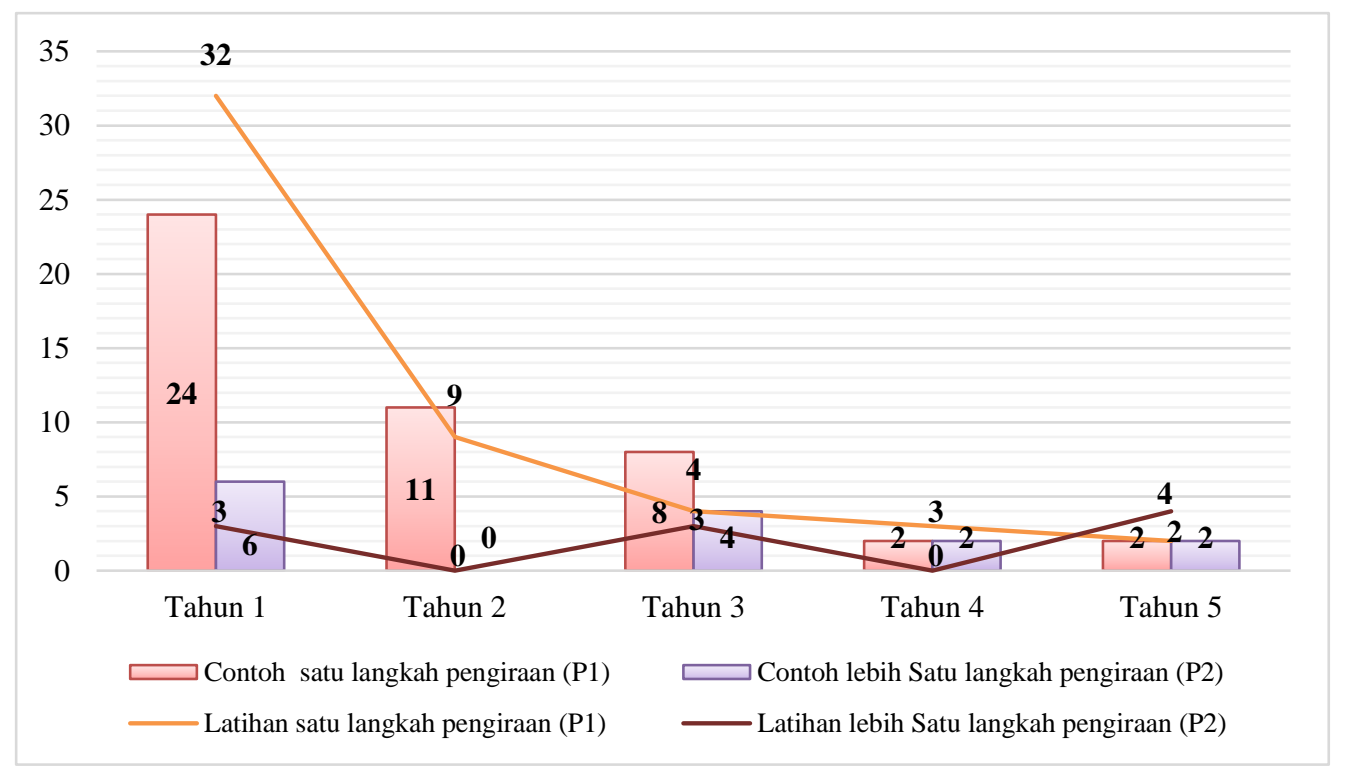

\section{Analisis Ciri-ciri Contoh dan Latihan Berdasarkan Aspek Kontekstual}

a) Analisis contoh dan latihan topik penambahan berdasarkan aspek matematik

Rajah 4 menunjukkan bahawa latihan dalam bentuk ayat matematik dalam buku teks matematik Tahun Satu, Dua, Tiga dan Empat adalah lebih banyak berbanding dengan contoh dalam bentuk ayat matematik. Akan tetapi, buku teks matematik Tahun Satu, Empat dan Lima tidak mempunyai contoh dalam bentuk ayat matematik. Berdasarkan Rajah 4, didapati bahawa contoh bergambar, bercerita dan berjadual dalam buku teks matematik Tahun Satu hingga Tahun Empat adalah lebih banyak berbanding dengan latihan bergambar, bercerita dan berjadual. Akan tetapi, buku teks matematik Tahun Lima hanya mempunyai latihan bergambar, bercerita dan berjadual.

Rajah 4: Analisis ciri-ciri contoh dan latihan topik penambahan berdasarkan aspek kontekstual

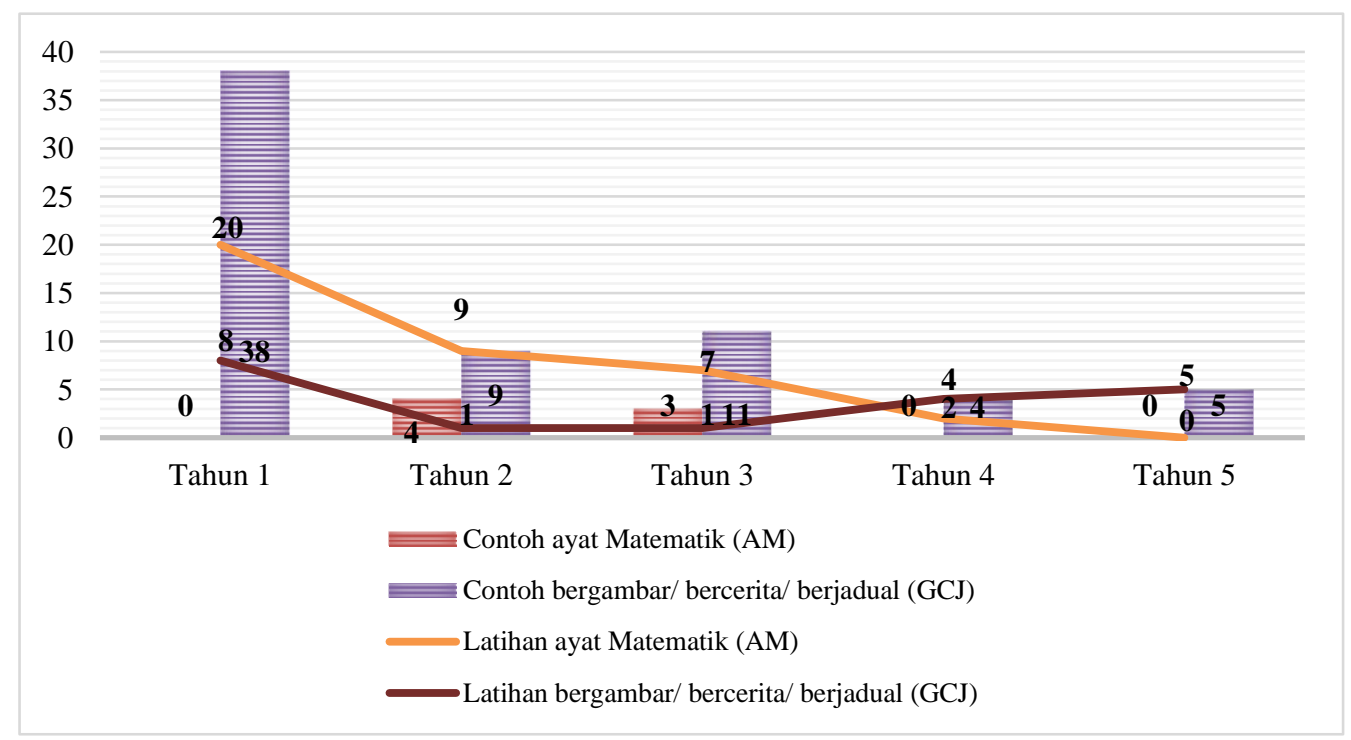

b) Analisis ciri-ciri contoh dan latihan topik penolakan berdasarkan aspek kontekstual

Menurut Rajah 5, latihan dalam bentuk ayat matematik adalah lebih banyak berbanding dengan contoh dalam bentuk ayat matematik bagi kelima-lima tahun. Selain itu, didapati bahawa Tahun satu, Empat dan Lima tidak mempunyai contoh dalam bentuk ayat matematik. Di samping itu, 
Rajah 5 juga menunjukkan bahawa contoh penolakan yang bergambar, bercerita dan berjadual adalah lebih banyak berbanding dengan latihan bergambar, bercerita dan berjadual bagi Tahun Satu hingga Empat, hanya Tahun Lima mempunyai bilangan contoh dan latihan bergambar, bercerita dan berjadual yang sama.

Rajah 5: Analisis ciri-ciri contoh dan latihan topik penolakan berdasarkan aspek kontekstual

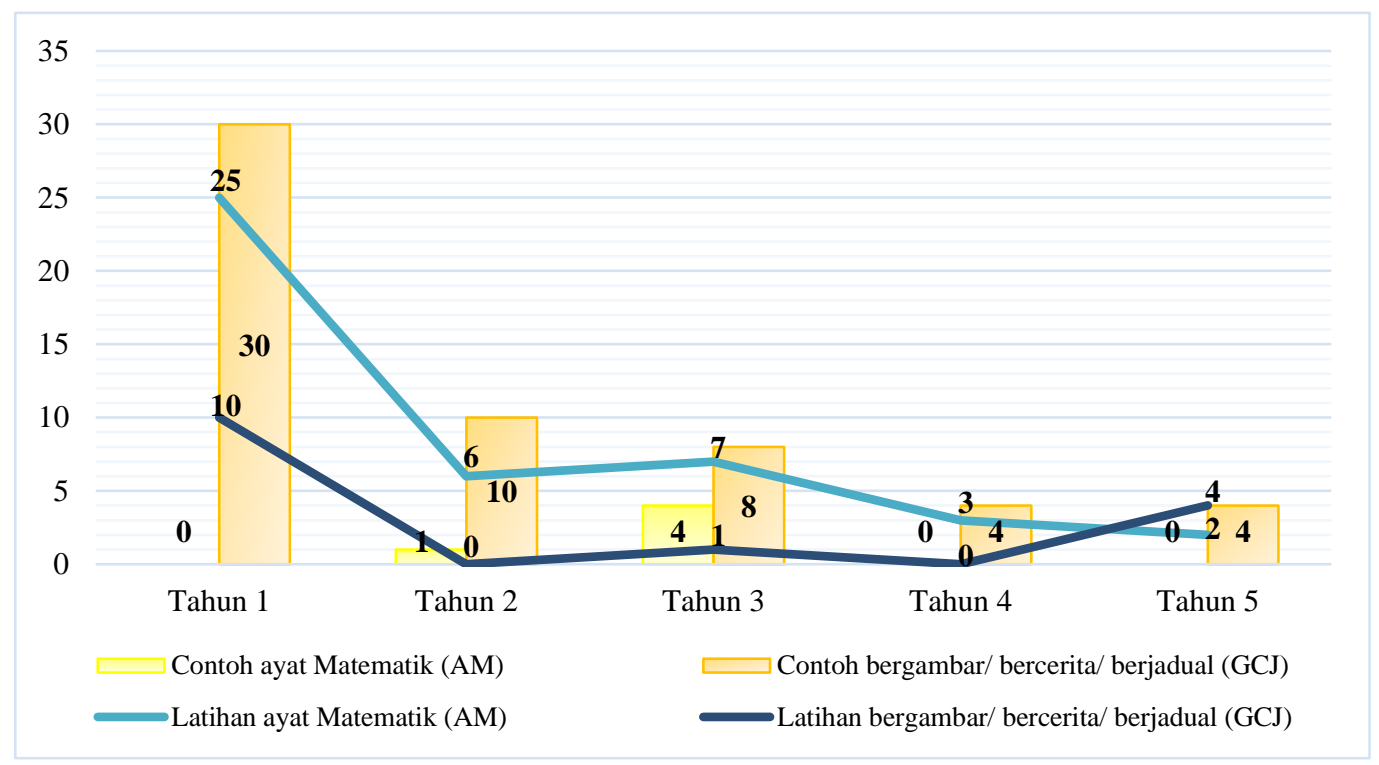

\section{Perbincangan Kajian}

\section{Bilangan Jenis Soalan}

Bilangan contoh dan latihan Tahun Satu bagi topik penambahan dan penolakan adalah paling banyak berbanding dengan tahun yang lain. Selain itu, contoh bagi kedua-dua topik adalah lebih banyak berbanding dengan latihan yang bertujuan membantu murid-murid menguasai konsep dan pengiraan penambahan dan penolakan membolehkan mereka mempelajari operasi yang lebih tinggi melalui pendedahan pelbagai kaedah penyelesaian kepada mereka. Hal ini disokong oleh Xia (2017) yang berpendapat bahawa contoh dalam buku teks mempunyai asas yang kukuh dan berkait rapat dengan konsep matematik. Namun, hal ini bercanggah dengan Wang (2017) yang berpendapat bahawa guru matematik cenderung menggunakan masa panjang untuk menerangkan contoh, akibatnya menyebabkan latihan dalam buku teks kurang diberi tumpuan. Akan tetapi Xia (2017) pula berpendapat bahawa contoh dalam buku teks matematik yang kurang, tidak dapat memenuhi keperluan pengajaran harian.

Walau bagaimanapun Pei et al. (2016) pula berpendapat bahawa dalam pembelajaran matematik, terutamanya topik nombor dan operasi, murid memerlukan latihan dan penerangan yang berulang kali untuk menguasai dan mengukuhkan pemahaman konsep agar dapat mengaplikasikannya ke dalam penyelesaian masalah yang sebenar dengan lebih baik. Pandangan ini disokong oleh Aperar Singh et al. (2020) yang menyatakan bahawa operasi penambahan dan penolakan merupakan operasi aritmetik yang paling asas dalam Matematik dan pemahaman konsep-konsep ini penting agar dapat membantu murid mengembangkan konsep lebih lanjut untuk operasi aritmetik yang lebih banyak.

\section{Aspek Matematik}

Soalan satu langkah pengiraan dalam buku teks Tahap Satu adalah lebih banyak berbanding dengan soalan lebih satu langkah pengiraan. Hal ini kerana aras kognitif murid Tahap Satu masih rendah, maka penggunaan soalan yang tidak mempunyai langkah penyelesaian yang banyak dapat membantu murid 
lebih mudah memahami konsep matematik dan meningkatkan minat mereka untuk terus belajar. Wang (2017) berpendapat bahawa tahap kesukaran latihan perlulah sesuai kepada semua murid. Hal ini kerana latihan yang terlalu sukar akan menyebabkan kebanyakan murid tidak dapat menjawab, manakala latihan yang terlalu mudah pula tidak dapat menggambarkan perbezaan pencapaian dan penguasaan setiap murid.

Akan tetapi, soalan lebih satu langkah pengiraan bagi Tahap Dua (Tahun Empat dan Lima) pula lebih banyak berbanding dengan soalan satu langkah pengiraan. Tahap pemikiran murid sekolah rendah semakin matang (Ho, 2018), soalan lebih satu langkah pengiraan dapat mencabar murid. Pandangan ini disokong oleh Tan et al. (2017) yang berpendapat bahawa adalah sesuai mula memperkenalkan kemahiran berfikir aras tinggi kepada murid pada Tahun Empat (10 tahun). Maka, pendedahan soalan yang lebih satu langkah pengiraan adalah sesuai untuk murid Tahap Dua. Seperti yang dikatakan oleh Xia (2017) bahawa soalan yang terlalu mudah tidak dapat memenuhi kehendak pembelajaran murid. Namun, Wang (2017) pula berpendapat bahawa pengiraan yang berlebihan pula akan menyebabkan kebebanan dan keletihan kepada murid.

\section{Aspek Kontekstual}

Berdasarkan analisis contoh dan latihan berdasarkan aspek kontekstual, didapati bahawa latihan dalam bentuk ayat matematik adalah lebih banyak berbanding dengan contoh dalam bentuk ayat matematik. Hal ini kerana setelah proses pengajaran, latihan dalam bentuk ayat matematik boleh digunakan sebagai alat untuk melatih kemahiran mengira murid. Pandangan ini selaras dengan Pei et al. (2016) yang menyatakan bahawa murid-murid memerlukan latihan yang berulang kali supaya mahir dalam pengiraan terutamanya bidang nombor dan operasi. Akan tetapi, kaedah persembahan buku teks matematik yang sama dan kurang menarik, tidak dapat merangsang perasaan ingin belajar murid dan mungkin menyebabkan mereka hilang minat untuk belajar (Wang, 2017). Oleh sebab itu, buku teks matematik banyak menggunakan contoh yang bergambar, bercerita atau berjadual agar merangsang minat murid untuk belajar. Wang (2017) berpendapat bahawa penggunaan gambar yang bermakna bukan sahaja dapat menarik minat dan perhatian murid tetapi juga dapat membantu murid memahami kehendak dan maksud soalan serta cara penyelesaian; penggunaan jadual dalam soalan matematik pula bertujuan mempersembahkan seluruh maklumat dalam bentuk yang ringkas yang turut memudahkan murid mendapat maklumat yang diperlukan. Selain itu, Pei et al. (2016) juga berpendapat bahawa bagi murid yang baru belajar penambahan dan penolakan, pemahaman konsep adalah penting, oleh itu penggunaan latihan yang bergambar dapat membantu murid lebih mudah memahami konsep.

Namun, penggunaan gambar yang bermakna boleh dikurangkan secara berperingkat demi melatih kemahiran imaginasi dan pemikiran murid yang turut dapat memupuk kemahiran menganalisis murid (Wang, 2017). Pandangan ini disokong juga oleh Pei et al. (2016) yang menyatakan bahawa latihan yang bergambar boleh dikurangkan, manakala latihan tanpa gambar boleh ditingkatkan. Hal ini selaras dengan hasil kajian ini yang menunjukkan bahawa latihan bagi kedua-dua topik kurang menggunakan soalan yang bergambar, bercerita atau berjadual berbanding dengan contoh.

Selain itu, didapati bahawa contoh dalam buku teks matematik banyak dalam bentuk cerita yang menghubungkaitkan matematik dengan kehidupan seharian murid. Penggunaan contoh yang mensimulasikan masalah kehidupan harian dapat melatih kemahiran penerokaan, menganalisis dan penyelesaian masalah murid (Wang, 2017). Pembelajaran berasaskan simulasi bukan sahaja dapat membantu murid menemui soalan dari perspektif matematik tetapi juga dapat meningkatkan kemahiran pengaplikasian pengetahuan dan kemahiran matematik ke dalam masalah matematik dengan praktikal (Ho, 2018).

\section{Kesimpulan}

Secara kesimpulannya, buku teks matematik merupakan sumber utama dalam proses pengajaran dan pembelajaran matematik. Contoh dan latihan merupakan bahagian penting dalam buku teks matematik. 
Hal ini kerana contoh dan latihan dalam buku teks matematik bukan sahaja dapat membantu murid menggabungkan pengetahuan baharu, tetapi juga dapat meningkatkan kemahiran berfikir murid.

Penyediaan contoh dan latihan yang seimbang dalam aspek bilangan dan aspek matematik dapat mengurangkan tekanan pembelajaran murid dan berfungsi mengukuhkan pengetahuan baharu. Akan tetapi, berdasarkan analisis kajian ini, didapati bahawa latihan bagi penambahan dan penolakan dalam buku teks matematik SJKC adalah kurang dan tidak cukup untuk mengukuhkan pengetahuan dan konsep penambahan dan penolakan murid. Hal ini turut menyebabkan guru matematik terpaksa mendapatkan latihan tambahan daripada buku kerja dalam pasaran. Selain itu, contoh dan latihan penambahan dan penolakan dalam buku teks matematik juga didapati lebih kepada soalan yang hanya melibatkan satu langkah pengiraan yang bertujuan untuk mengukuhkan konsep penambahan dan penolakan pada murid. Akan tetapi, hal ini turut menimbulkan masalah, di mana murid kurang berpeluang mengembangkan pengetahuan mereka ke tahap yang lebih tinggi. Tambahan pula, hal ini juga menyebabkan guru matematik dan murid semakin kurang menggunakan buku teks matematik sebagai sumber utama dalam pengajaran dan pembelajaran matematik mereka.

Selain daripada itu, buku teks matematik SJKC juga menyediakan banyak contoh yang bergambar, bercerita atau berjadual yang bertujuan membantu murid memahami konsep penambahan dan penolakan dengan lebih mudah. Hal ini kerana penggunaan gambar atau jadual dapat mempermudahkan dan meringkaskan kandungan yang perlu disampaikan dengan sebilangan bahasa yang kompleks, susun atur buku teks juga akan kelihatan meriah yang turut memudahkan penguasaan konsep matematik. Tambahan pula, penyampaian soalan matematik gabungan gambar dan teks adalah lebih mudah menarik perhatian murid sekolah rendah yang dapat memberi inspirasi kepada minat murid untuk belajar dan meningkatkan kesan pembelajaran murid. Pandangan ini disokong oleh Yang (2017) yang menyatakan bahawa murid perlu diberi peluang yang cukup untuk berlatih menyelesaikan pelbagai jenis persembahan soalan matematik yang terdiri daripada soalan matematik dalam bentuk perkataan, bergambar atau gabungan untuk memastikan murid memahami struktur masalah matematik.

\section{Rujukan}

Azriana Abdul Azis \& Roslinda Rosli. (2021). Analisis aras kognitif bagi soalan dalam buku teks matematik Tahun 4 KSSR Semakan. Malaysian Journal of Social Sciences and Humanities (MJSSH), 6(3), 146-158. https://doi.org/10.47405/mjssh.v6i3.712

Abdullah, Y., Mahmud, R., Jalil, H.A., \& Daud, S. M. (2016). Analisis kesalahan dalam menyelesaikan operasi penambahan dan penolakan pecahan dalam kalangan murid Tahun Empat. International Journal of Education and Training (InjET), 1(1), 1-8.

Alabdulaziz, M., \& Higgins, S. (2021). The compatibility of developed mathematics textbook content in Saudi Arabia with NCTM standards: A critical review. International Journal of Instruction, 14(2), 461-482. https://doi.org/10.29333/iji.2021.14226a

Aperar Singh, P., Mohd Yusoff, N., \& Teoh, S. (2020). Content analysis of primary school mathematics textbooks and its relationship with pupils achievement. Asian Journal Of University Education, 16(2), 15-25. https://doi.org/10.24191/ajue.v16i2.10286

Behnke Y. (2018) Textbook effects and efficacy. In: Fuchs E., Bock A. (eds) The palgrave handbook of textbook studies (pp. 383-396). Palgrave Macmillan, New York. https://doi.org/10.1057/978-1-137-53142-1_28

Bingolbali, E. (2020). An analysis of questions with multiple solution methods and multiple outcomes in mathematics textbooks. International Journal of Mathematical Education in Science and Technology, 51(5), 669-687. https://doi.org/10.1080/0020739X.2019.1606949

Brehmer, D., Ryve, A., \& Steenbrugge, H.V. (2016) Problem solving in Swedish mathematics textbooks for upper secondary school. Scandinavian Journal of Educational Research, 60(6), 577-593. https://doi.org/10.1080/00313831.2015.1066427

Chang, C., \& Silalahi, S. M. (2017). A review and content analysis of mathematics textbooks in educational research. Problems of Education in the 21st Century, 75, 235-251. https://doi.org/10.33225/pec/17.75.235 
Cheng, J. W., \& Roslinda Rosli. (2020). Analisis domain kognitif bagi latihan dalam buku teks matematik Tahun 6. Malaysian Journal of Social Sciences and Humanities (MJSSH), 5(11), 116126. https://doi.org/10.47405/mjssh.v5i11.549.

Digital Educational Learning Inititative Malaysia. (2021). Buku teks digital. Retrieved from https://sites.google.com/moe.edu.my/guru/buku-teks-digital

Dollah, M. U., Widjaja, W., Zabit, M., \& Omar, T. Z. (2019). A comparison of values of progress conveyed in mathematics textbook in Malaysia and Australia. International Journal of Asian Social Science, 9(2), 179-188. https://doi.org/10.18488/journal.1.2019.92.179.188

Gracin,, D. (2018). Requirements in mathematics textbooks: A five-dimensional analysis of textbook exercises and examples. International Journal of Mathematical Education in Science and Technology, 49(7), 1003-1024. https://doi.org/10.1080/0020739X.2018.1431849

Hadar, L. (2017). Opportunities to learn: Mathematics textbooks and students' achievements. Studies In Educational Evaluation, 55, 153-166. https://doi.org/10.1016/j.stueduc.2017.10.002.

Ham, A.V., \& Heinze, A. (2018). Does the textbook matter? Longitudinal effects of textbook choice on primary school students' achievement in mathematics. Studies in Educational Evaluation, 59, 133-140.

Ho, H. (2018). The characteristics of writing examples in the textbook of mathematics in China and Germany compare research: Take the fourth grade as an example [Master dissertation, Guizhou Normal University]. CNKI. https://wap.cnki.net/touch/web/Dissertation/Article/ 106631018836564.nh.html

Hwang, S., Yeo, S., \& Son, T. (2021). A comparative analysis of fraction addition and subtraction contents in the mathematics textbooks in the U.S. and South Korea. International Electronic Journal of Elementary Education, 13(4), 511-521.

Kementerian Pendidikan Malaysia. (2015). Dokumen Standard Kurikulum dan Pentaksiran Matematik Tahun 1. Putrajaya: Bahagian Pembangunan Kurikulum, KPM.

Kementerian Pendidikan Malaysia. (2016). Dokumen Standard Kurikulum dan Pentaksiran Matematik Tahun 2. Putrajaya: Bahagian Pembangunan Kurikulum, KPM.

Kementerian Pendidikan Malaysia. (2017). Dokumen Standard Kurikulum dan Pentaksiran Matematik Tahun 3. Putrajaya: Bahagian Pembangunan Kurikulum, KPM.

Kementerian Pendidikan Malaysia. (2018). Dokumen Standard Kurikulum dan Pentaksiran Matematik Tahun 4. Putrajaya: Bahagian Pembangunan Kurikulum, KPM.

Kementerian Pendidikan Malaysia. (2019). Dokumen Standard Kurikulum dan Pentaksiran Matematik Tahun 5. Putrajaya: Bahagian Pembangunan Kurikulum, KPM.

Lepik, M., Grevholm, B., \& Viholainen, A. (2015). Using textbooks in the mathematics classroom the teachers' view. Nordic Studies in Mathematics Education, 20(3-4), 129-156.

Lessani, A., Yunus, A., Tarmiz, R.B., \& Mahmud, R. (2014). Investigating the content of mathematics textbook used in 8th grade in Malaysia based on content domain of TIMSS. International Journal of Education and Research, 2(9), 71-84.

Li, Y. (2000). A comparison of problems that follow selected content presentations in American and Chinese mathematics textbooks. Journal for Research in Mathematics Education, 31(2), 234-241. https://doi.org/10.2307/749754

Lusiana, R., \& Andari, T. (2019). Developing an algebra textbook based on problem solving to improve student' learning achievement. Al-Jabar : Jurnal Pendidikan Matematika, 10(2), 293306. https://doi.org/10.24042/ajpm.v10i2.4906.

Makonye, J. P., \& Fakude, J. (2016). A study of errors and misconceptions in the learning of addition and subtraction of directed numbers in Grade 8. SAGE Open, 6(4), 1-10. https://doi.org/10.1177/2158244016671375

Mullis, I. V. S., Martin, M. O., Goh, S., \& Cotter, K. (2016). TIMSS 2015 Encyclopedia: education policy and curriculum in Mathematics and Science. http://timssandpirls.bc.edu/timss2015/encyclopedia/

Ng, L. K., \& Dindyal, J. (2016). Examples in the teaching of mathematics: teachers' perceptions. In P. C. Toh., \& B. Kaur (Eds.), Developing 21 st century competencies in the mathematics classroom (pp. 189-212). Singapore.

Norberg, M. (2019). Potential for Meaning Making in Mathematics Textbooks. Designs for Learning, $11(1), 52-62$. 
Noriati A. R., Boon, P. Y., \& Sharifah F. S. A. (2017). Murid dan Pembelajaran. Shah Alam: Oxford Fajar Sdn. Bhd.

Norqvist, M. (2018). The effect of explanations on mathematical reasoning tasks. International Journal of Mathematical Education in Science and Technology, 49(1), 1530. https://doi.org/10.1080/0020739X.2017.1340679

Pei, L., Shang, J., \& Ma, Y. (2016). The comparative study of exercises in two versions of mathematics textbooks for Chinese elementary schools: A case study of number, addition and subtraction within 20. Curriculum, Teaching Material and Method, 36(6), 68-75.

Reyhani, E., \& Izadi, M. (2018). Comparative content analysis of mathematics textbooks taught to the First Grade students of elementary schools in Iran, Japan and America. International Journal of Industrial Mathematics, 10(3), 299-314.

Asyrani Abdul Samat \& Roslinda Rosli. (2020). exploring teachers' perceptions of primary school mathematics textbook. International Journal of Academic Research in Progressive Education and Development, 9(1), 286-300.

Stará, J., \& Krčmářová, T. (2015). How teachers reflect on textbook materials and how they utilise them. Internatioal Association for Research on Textbooks and Educational Media e-Journal, 6(3), 67-87.

Tan, K. J., Ismail, Z., \& Abidin, M. (2018). A comparative analysis on cognitive domain for the malaysian primary four textbook series. Eurasia Journal of Mathematics, Science and Technology Education, 14(4), 1273-1286. https://doi.org/10.29333/ejmste/82625

Wang, Y. C. 2017. The research on classroom exercises using in the primary mathematical textbook: To PEP as an example [Master dissertation, College of Education, Central China Normal University]. https://wap.cnki.net/touch/web/Dissertation/Article/10511-1017251751.nh.html

Xia, K. 2017. Investigation of mathematics teachers in Changzhou and Wuxi City on understanding and using of the textbook examples [Master dissertation, Nanjing Normal University]. CNKI. http://61.181.120.82:8081/kcms/detail/detail.aspx?filename= 1020326117.nh\&dbcode $=$ CMFD\&dbname $=$ CMFD2021

Yang, D., Chang, M., \& Sianturi, I. A. J. (2017). The study of addition and subtraction for two digit numbers in Grade One between Singapore and Taiwan. American Journal of Education and Learning, 2(1). 75-82. https://doi.org/10.20448/804.2.1.75.82.

Yang, Y. 2019. A comparative study of the example design in mathematics textbooks in Chinese and Singapore junior high schools: Taking Shanghai Education Version and New Express Mathematics Used in Singapore as an example [Master dissertation, Hunan Normal University]. CNKI. https://wap.cnki.net/touch/web/Dissertation/Article/10542-1019672528.nh.html

Yeh, C. Y. C., Cheng, H. N. H., Chen, Z. H., Liao, C. C. Y., \& Chan, T. W. (2019). Enhancing achievement and interest in mathematics learning through Math-Island. Research and Practice in Technology Enhanced Learning, 14(1), 1-19. https://doi.org/10.1186/s41039-019-0100-9 